\title{
Nationalism in the Contemporary World: Theoretical Approaches and Empirical Implementations
}

\author{
Denis Chistyakov \\ “STREAM” Television Company", CJSC \\ Moscow, Russia \\ E-mail: chistyakov.d@gmail.com
}

\begin{abstract}
The article considers nationalism of various forms as a relevant phenomenon of the modern world. Nationalism is defined as a political ideology coupled with a certain social practice. The author analyzes the theories of nationalism belonging both to Russian and foreign scientists, reviews peculiarities of civil, liberal and state types of nationalism. Special attention is paid to ethnic nationalism, its causes and socio-cultural consequences. The author substantiates the necessity of civic nation formation in Russia in order to prevent the occurrence of negative forms of nationalism and to overcome the inter-ethnic problems. The author pays attention to the nation state concepts and to the practical possibilities of the consociation democracy.
\end{abstract}

Keywords-ethnic nationalism; state nationalism; statebuilding; ethnicity; nation; nation state; consociation democracy; ethno-political model of state; K. Lefort; E. Gellner

\section{INTRODUCTION}

Nowadays nationalism has quite widespread forms and types as a social and political phenomenon. However, the theoretical analysis of its essence, specific differences, comparative characteristics, tendencies of its development in the Russian society from the nation-building point of view, possibilities of its transforming into extreme nationalism and extremism has not been sufficiently covered in the social and humanitarian field of scientific research. The concepts of «nationalism», «fascism» and «racism», as well as types of nationalism originating from either cultural-ethnic or political conditions, are often mistaken.

\section{ON DEFINITION OF NATIONALISM}

When defining the premise of nationalism, the most important step is to reveal the primary sources of nationalism. It should be noted that nationalism, fundamentally, does not imply any hatred towards people of different nationalities but only stipulates a nation's exclusiveness in comparison to other nations. Z. Freud advocates this thesis in his works. In comparison with a different nation, one will always prefer his/her own nation. However, it is often just impossible to explain it in terms of logic, since the reasons for such preference are rather irrational and probably even instinctive. In some cultures, individuals are brought up with the understanding of the uniqueness and selectees of their nation, and this is how the basis for patriotism and «healthy» nationalism is built. Meanwhile, if the individual finds himself in a different socio cultural environment, the liberal nationalism (similar to patriotism) can «mutate» into its aggressive form. It can sometimes be stimulated by certain works of literature, music, speeches of state and political leaders, and/or by a psychological environment overemphasizing specific ethnic features of a nation, etc.

According to the author, nationalism is a political ideology combined with social practice, when nation acts as a court of sovereignty. In nationalism studies, a nation, as a rule, is seen as an independent and self-sufficient formation, existing in reality (nation state), or as the goal of the socalled "nationalizing" states. From the citizens' point of view, shared values, interests, traditions, and linguistic culture are given priority over the history and culture of other nations. Here lies the possibility of nationalism's emergence, despite that in its "healthy" form it is akin to patriotism. However, it is quite difficult to define the criteria of such "healthiness" and to catch the point at which nationalism becomes destructive.

Let us identify the key points of nationalist ideology: national self-identification, perceiving oneself as part of a nation; the understanding that one nation has the uppermost value claiming the exclusiveness of the nation; a grouporiented position - nationalists speak on behalf of the whole nation, however when scrutinizing them, it becomes clear that they only express the ideas of a certain group.

\section{ThE TYPOLOGY OF NATIONALISM}

The typology of nationalism found in social science literature is also rather multidimensional, with various conceptual substantiations and methodological presuppositions of the authors. We will try to make a general survey of the most acceptable theoretical approaches in defining the sociopolitical essence and kinds of nationalism. The first attempt to create a typology of the phenomenon was made by historian Meinecke in his book «Cosmopolitanism And The National State» (1907), where he pointed to a fundamental difference between political and cultural types of nations. This idea was later developed by $\mathrm{H}$. Kohn in his work «The Idea Of Nationalism» (1944), where he stated that in England, France and the USA nationalism was basically political, while in Central and Eastern Europe, as well as in Asia, it was ethnic. Today, most scientists tend 
to agree that each nation comprises both of these components. According to the latest research, Western Europe is today characterized by a strong cultural constituent while Central and Eastern Europe rely on the civic constituent. This is exclusively due to the importance of an integrated culture and domination of liberal and democratic values for the existence of a nation.

Let us characterize the above-mentioned typologies of nationalism. When identifying civic nationalism as a social and political phenomenon, the idea is strong that the legitimacy of the state is determined by active participation of its citizens in the process of political decision-making, i.e. by the extent to which the state represents «the will of the nation». The basic tool for defining the will of the nation is a plebiscite which can be conducted in the form of elections, a referendum, a poll, an open public discussion, etc. In such cases the person's nationality is defined on the basis of a voluntary personal choice and is identified with citizenship.

Civic nationalism is divided into two subcategories: state nationalism and liberal nationalism. State nationalism is the theory of nation formation by the people subordinating their own interests to the problems of strengthening and maintaining the power of the state. This type of civic nationalism does not acknowledge the independent interests and rights related to sex, race, or ethnicity as it is supposed that such autonomy breaks the unity of the nation. Supporters of liberal nationalism, on the contrary, stress liberal values and claim that patriotic and moral categories come after universal norms, such as, for example, human rights.

However, the ethnic identification in nationalism discourse is expressed typically in the form of ethnic nationalism. Despite the increasing migration flows, ethnic nationalism stands its grounds. The American scientist G. Müller, noting the willingness of immigrants coming to the US to accept the traditions and values of their new homeland, argues that "to those people, living on the land of their ancestors, that had settled there several generations or even centuries ago, political self-identification often coincides with ethnic one. As a result, ethnic communities are starting to claim their own statehood" $[1$, p. 21]. This is how the conditions for ethnic nationalism as an ethnic ideology emerge.

In this context, ethnic nationalism focuses on the «organic unity» of the people forming the nation which can be of cultural or genetic nature. Cultural traditions or ethnic affiliation can become the basis of nationalism if they contain common views and a common historical memory as a reference point for the society. At the same time, as oral tradition in itself and personal experience often prove to be insufficient for this purpose, the means of communication (language, media, literature, etc.) play an extremely important role.

As a matter of fact, ethnic nationalism is a movement intended for struggling to make the ethnic and political boundaries of communities coincide and to make the ethnic community politically independent. The disintegration of Yugoslavia, Czechoslovakia, and the USSR are the brightest displays of ethnic nationalism, but they are not unique. Norway and Sweden peacefully split in 1905, giving sovereignty and independence to Norway.

\section{ETHNIC NATIONALISM: HistORY AND MODERN IMPLEMENTATIONS}

The exaggeration of values, imperatives, myths of shared history, linguistic and cultural homogeneity is common to ethnic nationalism. The idea of ethnic self-value and absolutizing of its importance prevails.

The process of the ethnic identification goes by as opposed to another ethnos ("Us-Them") closely connected with an excessive prevalence of forms and ideas of nationalism. Such identification of ethnos not only takes place in scientific literature, but in the ethnic consciousness as well. In this case, a universal idea may originate inside of the ethnos stating that a specific nation is better than the others; that it is opposed to a different ethnos "not without a reason", as its culture, traditions, the way of life are more "correct". A whole complex of economic, political and social-psychological factors can be conditionally designated as «Our». The idea of "ours" can be within the limits of the norm for distinguishing healthy groups or ethnic consciousness. But under certain circumstances it can develop features of and exaggerated «Ours» as opposed to "Not ours", while "ours" ethnos can be overemphasized and positioned as the best option. In this case, it becomes possible that ethnicity is used for political purposes by politicians, businessmen, clan groupings, and pseudo religious figures. Here, a way out can be found in the values and the norms of life in all nations that are defined today as tolerant, broad-minded, and neighborly.

According to the Russian researcher V.S. Malakhov, nationalism arises when two levels of reflexive problematics are mixed: "sovereignty" and "identity" [2]. Ethnic group sovereignty is not cut from its identity, from its "Us" as a community. The political overlaps coincides with the cultural and ethnic aspects. Probably, that fact would not cause negative effects but, as rightfully noted by E. Gellner, people have a tendency to make exceptions for themselves, this being a "basic human weakness from which all other weaknesses are derived; it strikes a nationalistic feeling as well. Probably, political manifestations of nationalism would be much more moderate if the nationalists would be aware of the injustice towards them" [3, p. 25].

The ideology of nationalism formulates a number of arguments that cause ethnic conflicts when absolutized. These arguments are: "First, the myth of the general past of all ethnical group members; second, the myth of the group's linguistic and cultural homogeneity; third, the myth of the group's living space density. These three arguments are usually used to claim the secession on the ethnic basis" [2, p. 247]. According to J. Müller, the essence of ethnic nationalism is that nations are defined by common heritage, language, faith. Ethno-cultural differentiations, as a rule, get strengthened by "civilizational" and religious factors. These ideas, presented "rightly and timely" by the ethnic intellectual elite, make each nation the bearers of truth, 
"rightfulness", legitimacy of power. "Hegel noted that tragedy is not in the conflict of right and wrong, but in the conflict of right and right. This, usually, is the nature of ethnic conflict" [3, p. 19].

The main provision of ethnic nationalism reads that nations are not "imagined communities" (B. Anderson) or "fictions" (E. Gellner), but the existing matter that shall have representing statehood. A state, thus, shall include representatives of one nation. Political and ethnic thus coincide. The requirement of combining statehood with the national borders of one ethnic nation lead to hazardous situations, conflicts, extremism, separatism and xenophobia. Nationalism, demanding theoretical alignment of state and ethnic nation, puts all other peoples living in a polyethnic state, into an almost subordinate position. Lord Acton noted in 1862 that depending on the degree of humanity and civilization of the dominant (titular) nation, claiming all social rights and privileges, "inferior races" were subjected to genocide, enslaved, outlawed or put into dependent position [1]. The history of mankind is full of such examples: so happened after the death of empires (cf. the Romanovs, the Habsburgs), after World War II etc. The process of "combining state and monoethnic nation(s)" led to voluntary emigration because of discrimination, deportation, genocide. The definition "ethnic cleansing" reflects real processes happening in failing or de facto established states.

Despite the fact that ethnic nationalism may lead to the escalation of conflicts, at the same time it contributes to the unity of the ethnic group involved. Expressed through liberal democracy, ethnic nationalism may stabilize the situation in the state. W. Churchill, addressing the compatriots in the wartime, called them "gallant islanders" that psychologically supported and rallied the nation. From J. Müller's point of view, Europe has achieved the harmony in the postwar period largely due to the success of ethnic nationalism since it had eliminated the major sources of internal conflicts.

Ethnic nationalism simultaneously generates solidarity and feud. That is why ethnic nationalism cannot be expressed in definite categories and values; we cannot paint it black or white. The negative effects of ethnic nationalism dominating can partially be overcome by consociation democracy. Consociation democracy supposes the following: proportional representation of ethno-cultural groups when appointing key positions and distributing power and resources; proportional parliamentary representation; mutual veto rights or qualified majority when adopting the most important decisions. Consociation democracy in fact means securing the place of power for a particular nation / ethnic group. Such principles are found in coalitional cabinets of the governments of Belgium, Malaysia, Switzerland and other countries. However, the principles of consociation democracy only partially solve the problem of emerging conflicts, extremism and extreme forms of nationalism. Moreover, the implementation of consociation democracy principles is not effective at the stages of formation of nation states, as the process of nation-building presupposes departure from the ethnic state structure and the refusal of power provision on ethnic basis. A nation state is being created on the basis of civil and political union of all people, regardless of their ethnicity and cultural identity.

\section{EXTREME FORMS OF NATIONALISM}

A danger of transition to forms of extreme nationalism lies in overwhelming or excessive use of ideas of ethnic nationalism when reference to ethno-cultural uniqueness forces the ethnos to position itself as the best one, to oppose itself to other, ostensibly "lower" nations. The forms of extreme nationalism include: everyday nationalism, xenophobia, fascism, racism, neo-Nazism.

Extreme forms of nationalism are quite often associated with extremism and lead to acute internal or interstate conflicts. The aspiration of a nation living inside the country to create its own state leads to separatism. Radical state nationalism is a key component of fascism and Nazism. Many ethnic nationalists share ideas of national superiority and national exclusiveness as well as cultural and religious intolerance. They prove their point of view mostly with fictitious history and an extremely loose construction of facts or disputable historical situations.

It is important to emphasize that one of the characteristics of nationalism is the somewhat blurred ideology allowing to resort to a double-standard policy. For example, it is easy to accuse a small nation striving for independence of chauvinism and to label the struggle of small nations against (actual) slavery as separatism. However, here it is also necessary to be very careful with these concepts as it is a very precarious sphere where a rash word can lead to unforeseen and extremely unpleasant consequences.

Types of extreme nationalism and manifestations of extremism demand the special steadfast attention of Russian scholars. With extreme forms of nationalism and extremist movements, nations (separate groups of population) see a threat to their social and cultural identity in representatives of a different religion, culture, state, in the notion of «generalized alien»; find an enemy in a different ethnos which as it seems to them is "defective", insufficiently developed and lower in relation to the exclusiveness of their own people (chauvinism). According to Sova Research Center [4], xenophobia is especially characteristic for those social strata the position of which has worsened over the past years or is unstable. It is strongly expressed in students of professional technical schools, young workers and schoolchildren living in small towns in a crisis situation and also in megalopolises where all social conflicts are extremely exposed. It is cultivated by extremist ultranationalist groups, organizations of skinheads and the like, and there are often certain political forces behind the spontaneous youth extremism. At the same time, xenophobia becomes directed against individual migrants (or groups of migrants) but not against the import of foreign culture.

An analysis of the reasons and possible consequences of nationalist manifestations of various political groups and organizations, extremist movements, including youth movements, are necessary. The ideas of forming the national state on the basis of a tolerant attitude to various cultures, religious communities, to ethnic features and traditions of all 
nations living in one territory, are perceived as excluding both forms of extreme nationalism and extremism in Russia.

\section{THE PROBLEM OF ETHNOS: NATION INTERRELATION IN RUSSIA}

The fundamental questions for the discussion of problems and foundations of ethnic nationalism are the questions on the ethnos-nation interrelation and the existence of ethnicity as an indispensable condition and principle of national state forming. More specifically, that ideology and nationalism are attributes of the nation as reality, expressed as the goal in the cases of nationalizing states.

There is a popular belief in Russian humanities literature that ethnicity is the basis of statehood, while the conformity between state and ethnic boundaries means the creation of the national state. At this point, there is a difficulty with correlating between the territorial borders of a given state and the boundaries of a given ethnos, as the majority of the states are now polytechnic. (For example, the states of Latin America, the Swiss Confederation in which territorial and political ties prevail over ethnic ties).

It should be emphasized that the question of a state's ethno-political system in the context of nation-building is rather debatable in the scientific literature. Some Russian scholars claim that ethnicity cannot form the basis for the state system and even for municipal division. With such a principle of state-building, the ethno-political model of forming the body of the state is created which provides conditions in which the local ethnic communities comprising the state start to identify themselves first of all with their own national-state entity instead of the state unity as a whole. As a result, the common civic foundations become weaker. In this case, it is implied that the ethno-political model of statehood complicates the process of nation-building and can in some cases even cause the dissolution of the states, as in the examples mentioned above. In particular, philosopher $\mathrm{G}$. I. Gribanova notes that «national-territorial federalism [underlying the Russian statehood-author] is a ticking time bomb» [5, p. 11] as, simultaneous with gradual creation of the nation state, ethnic identity and ethnic consciousness grow without an idea that would integrate all ethnicities. Thus, it turns out that deep ethnic identity of one ethnos (often confabulated, acquiring artificial historical and religious properties) can make a name for itself either by an intention to break away or by conflicts which are provoked or occur spontaneously. Therefore, the ethnic principle of building the state does not promote the formation of nationwide consciousness of the residents of ethnic peripheries and the nations that are not «titular» in this or that region.

Nevertheless, it is ethnicity that quite often serves as an ideological substantiation for the creation of the national state. It is worth noting that the integrating, system-building basis of ethnicity itself is embodied in culture and history; in other words, it is the cultural-psychological complex manifested in the form of special ethnic connection, symbolically and anonymously uniting people in a special commonality, establishing by means of symbolic agents, organic connections and interactions of both the generations living at present and the generations that lived in different centuries, in different historical forms of ethnicity. The nature of ethnicity unites people on the basis of common values, moral imperatives, relics, historical memory and while developing it can and should carry out the integrating function in nation-building as well.

Professor M.O. Mnatsakanyan claims that national commonality as a collective integrity is the modern specific historical form of ethnicity. Moreover, the internal nature of ethnicity «works», creating a national commonality manifesting itself in national movements for creation of the national state, for unity of territories, and for the stability of a normal communal life. «The internal nature of ethnicity and its properties remain, a special ethnic internal connection is kept, but there is a qualitative change in their empirical measurements, forms of manifestation, the ways and character of action and interaction of various system elements. Ethnicity never manifests itself anywhere in the "pure" and empirically recognizable form. In search of it we always come across a specific form of it which will be named a tribe, a nationality, or a nation» [6, p.158-159].

Civic commonality becomes the dominating core of the nation where territorial and political factors turn out to be the decisive ones. The state national policy is formed and national interests become the ideological basis of all political life. With a developed civil society, nation-building becomes an expedient and purposeful action not only of the state but also of public institutes. Russia is now trying to carry out this very purpose.

Modern-day Russia is considered today as "nationalizing state", which only in the future will acquire the status of the nation state; nowadays there is a goal of gradual civil society formation.

The author proceeds from viewing nation as civil and political union of people, sharing common cultural and value basis, inhabiting a common territory and independent from the ethnic principle of state structure. Exactly this understanding of a nation as civil-political union of various ethnicities living in Russia, offers the possibility of bringing together different ethnic cultures.

In other words, the idea of a united civic nation implies a diversity of ethnic cultures, existing in peaceful cooperation. In the sphere of state policy, an ethnic component should not play any role. Ethnicity is a principle that unites people, yet ethnicity should only matter in questions of culture, language, history, religion etc.

Let us emphasize that the concept nation state fully expresses the essence of the civilizational movement of the Western states and is the future for Russia. The tendency today is that the traditional ethno-political states are in process of transforming into civic nations or nation states.

In the transformation of any state to the nation state there may be a risk that the French philosopher Claude Lefort (1924-2010) called a paradox of democratic legitimacy. From his point of view, the difference of republic (i.e. democracy) from non-democratic forms of government (e.g. monarchy) is in the radical liberation of the place of power. 
In dynastic societies the place of power is reserved for the representatives of a certain family. In democratic societies the place of power is potentially empty. Only the people authorize those who are about to take that place. Thus, the only source of power in a democratic society is people or nation.

We shall note, however, that the empty place of power in the transitional period of the formation of a new nation states may be occupied not only through the democratic procedures, but also by the bureaucratic and nationalistic. Ethnic political elites, bearers of nationalist ideology under certain conditions, may occupy the place of power and control. Within here lies the next problem of interethnic relations in transitioning societies: the threat of ethnic nationalism and the emergence of conflicts, xenophobia and extremism.

In modern-day societies the threat of conflicts emergence still remains. The problem is acute and here to stay as national-governmental formations act as a basis of statehood. Politicization of institutionalized ethnicity has not disappeared in the post-Soviet period, but is actually nascent in the many ex-USSR states. The Russian philosopher Olga Chistyakova, analyzing the aforementioned transition to nation states, notes: "In the ex-USSR states the process of national identification took place in order of gaining the place of power, often taking the form of extreme ethnic nationalism. Ethno-nationalist politics provoked interethnic conflicts. Armenian-Azerbaijani, Tajik-Afghan, GeorgianAbkhazian, Ossetian-Ingush, Chechen - the ethnic character is recorded in the very names of the conflicts. These facts do not let us to forget them, i.e. some of these conflicts escalated into military action and continue up to this day" [7, p. 10].

In order to solve the problems of ethnic conflicts in some of the Russian regions, the officials started implementing the principles of consociation democracy (e.g. in Dagestan) with a proportional representation of local ethnical groups appointed to the key positions in power and control. Let us refer to the ideas of the Russian philosopher M. Bilalov, who believes that "the Russian Constitution shall meet regional cultural-political specifics and secure officially the principle of consociation democracy" [8, p. 70]. At the Russian nationbuilding stage, the consociation democracy is intended to fulfill the principle of the just distribution of power resources to the representatives of ethnic communities.

Still, let us emphasize once again that this type of democracy may play a positive role only at a certain stage of gathering the numerous ethnic groups living on the territory of one state. For the formation of civil-based nation, on the contrary, there should be a gradual departure from the principle of "ethnic places" in governmental structures. And this is the task Russia is required to perform in its formation of nation state and national culture.

Nation-building is a long process of consolidation of all ethnicities and cultures, living in the country (we are primarily discussing Russia here). During this process, ethnicity needs to be apolitical, subjected to the priority of human rights and freedoms - the universal values. We shall radically change our attitude to ethnicity and to get rid of its political framing. There should be no ethnic-territorial and administrative-territorial polities, but only one-the latter one. However, this does not mean that the author proposes to deal with ethnicity or denies the ethnic culture. Sustaining ethnicity beyond the governmental structure at the same time means the development of ethnic cultures. It just means that ethnicity shall not be framed via state, or else it leads to the establishment of ethnocratic states.

\section{CONCLUSION}

A personal sense of belonging to a particular ethnocultural community should not be at odds with the simultaneous feeling of belonging to a civil society called "nation". Under the terms of civic nation, one identity (ethnic) is complemented with the other one (nation, Russian e.g.), based on solidarity, patriotism, human values. The diversity of identities doesn't abolish ethnic culture, language, religious background. Under that conditions ethnic culture gets developed and promoted. However, in the system of political relations, ethnic factor shouldn't play a big role, and ideally should be removed from the political sphere as independent and self-worth. Human values and legal dominants shall prevail in politics. The preservation of ethnic culture and the possibility of ethnic identification are the most important tasks on the way to nation building.

In a state with a developed civil society, which can only be created under the conditions of genuine democracy, an "empty" (in terms of C. Lefort) place of power can and must be occupied by a nation as an actually existing civil society. Nation, in this context, is not just a formal basis of sovereignty and not an "imagined community" (B. Anderson). A nation is a real, civil, unity of people united not only by territorial boundaries, but also by values, moral principles, common language and political factors.

\section{REFERENCES}

[1] Muller J. Us and Them. The Enduring Power of Ethnic Nationalism. // Foreign Affairs. № 2 (March-April). 2008 г.

[2] Malakhov V.S. Nationalism as a political ideology. M.: KDU, 2005.

[3] Gellner E. Nations and Nationalism. M., 1991.

[4] http://www.sova-center.ru/racismxenophobia/publications/2014/02/d29004/.

[5] Gribanova G.I. // Politex. Transcript of the round table "Ethnopolitcal problems in modern Russia". 2005. www.politex.info.

[6] Mnatsakanyan M.O. Cultures. Ethnicitites. Nations. Reflections on the origin and nature of the national community. MGIMO University Publishing. M., 2005.

[7] Chistyakova O.V. The problems of ethno-cultural policy of nationalizing state. // Vestnik RUDN. 2010. № 4.

[8] Bilalov M. On the prospects of civil nation shaping in Dagestan. // Central Asia and Caucasus. Journal of social and political studies. V. 15. Ed. 2. 2012. 